\title{
PSYCHE
}

$\begin{array}{lll}\text { Vol. 7I } & \text { DeCEMBer, I964 } & \text { No. } 4\end{array}$

\section{REVIEW OF THE CALVERTIELLIDAE, WITH \\ DESCRIPTION OF A NEW GENUS FROM \\ PERMIAN STRATA OF MORAVIA \\ (PALAEODICTYOPTERA)}

\author{
By Jarmila Kukaloví* \\ Charles University, Prague
}

The extinct order Palaeodictyoptera now includes some twenty families, which appear to represent many lines of evolution radiating in different directions. Most of them resemble the Ephemeroptera, at least superficially, more than any other order of living insects but a few show some features highly suggestive of the Odonata and Protodonata.

The most notable of the latter is the family Calvertiellidae, now represented by Calvertiella Tillyard from Lower Permian deposits near Elmo, Kansas, and by Moraviptera Kukalová from the very base of the Lower Permian strata in Moravia (Zbýsov). Recently, some remarkably preserved fossils belonging to a new genus were found in Moravia at the Obora locality. Since both fore and hind wings are preserved, they add a great deal to our knowledge of this group of Palaeodictyoptera. The present paper consists of a review of the Calvertiellidae and the description of the new genus Moravia from Czechoslovakia.

Calvertiella was originally (1925) placed by Tillyard in the family Protagrionidae within the order Protodonata, but this was before the Protodonata (as well as Odonata) were known to lack the veins $\mathrm{MA}$ and $\mathrm{CuA}$. The family Calvertiellidae, established by Martynov in 193I, was transferred to the Palaeodictyoptera by

\footnotetext{
*Current address: Biological Laboratories, Harvard University.

This research has been aided by a National Science Foundation Grant, No. NSFGP - 2038. I am much indebted to Professor F. M. Carpenter, who made it possible for me to study the type of Calvertiella and who was very helpful in the preparation of this paper.
} 


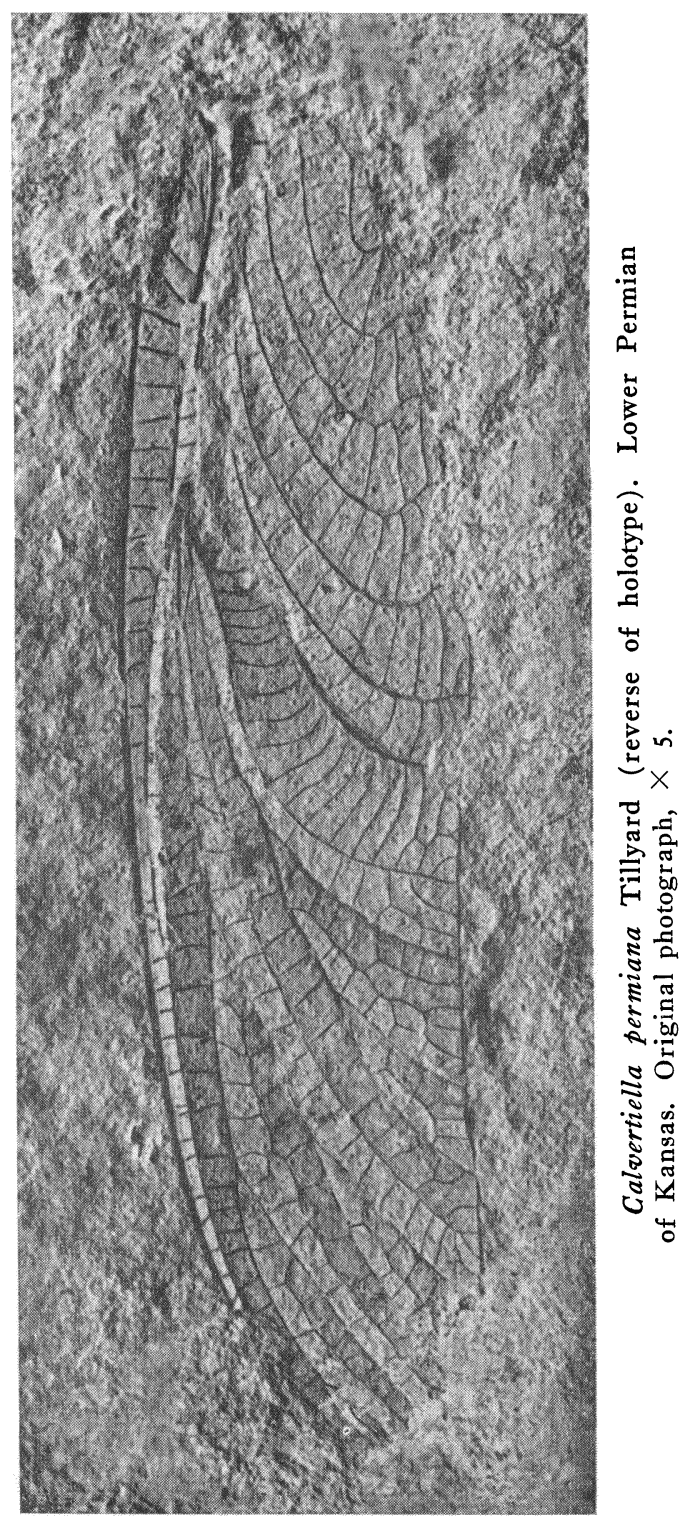




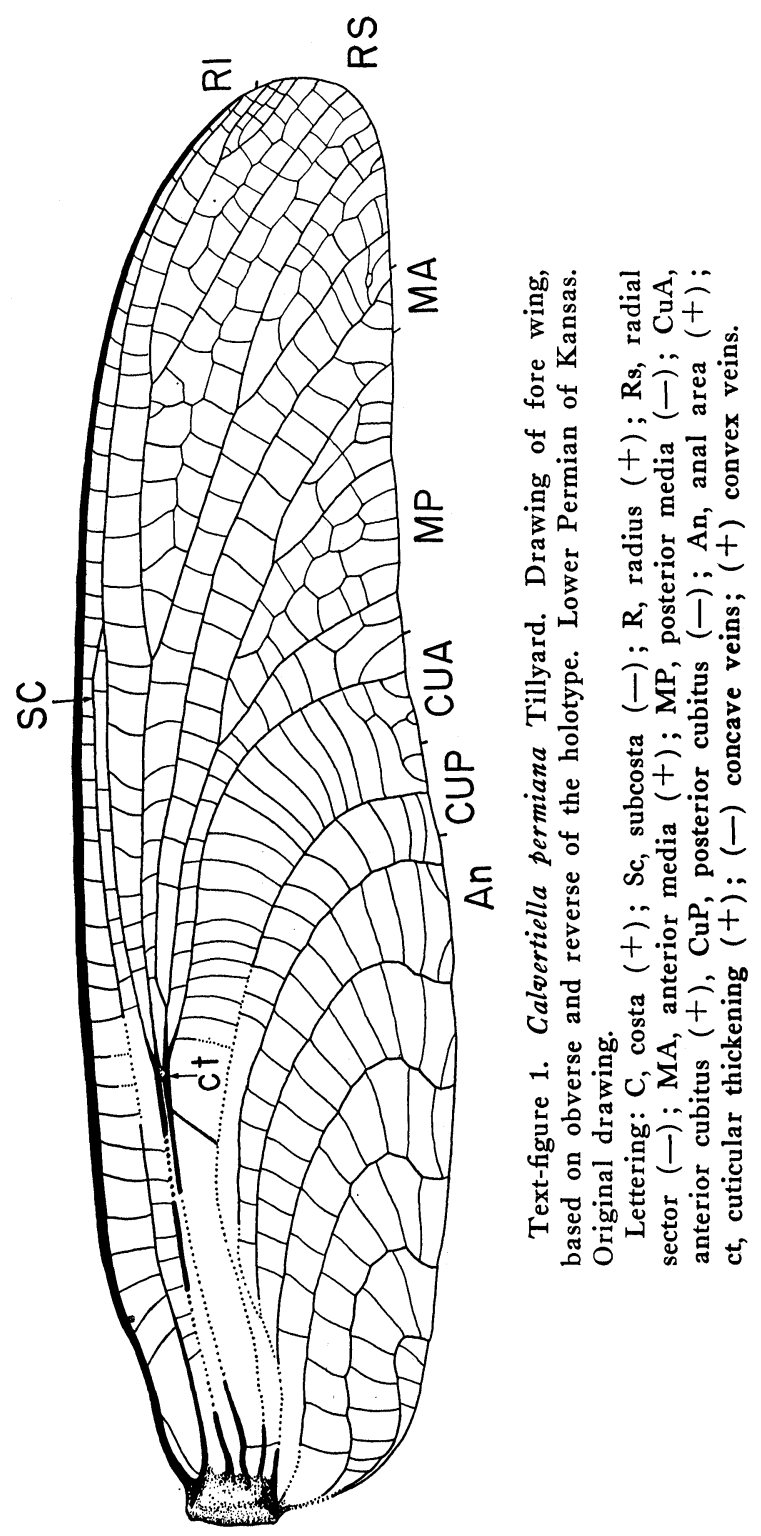


Handlirsch in 1937 , along with the Protagrionidae. Since then, both families have been treated as Palaeodictyoptera. ${ }^{1}$

\section{order Palaeodictyoptera golden berg Family Calvertiellidae Martynov, I93I}

Calvertiellidae, Martynov, 1931, Bull. Acad. Sci. URSS, $1: 146$ [Protodonata (Meganisoptera) ]; Handlirsch, 1937, Ann. Naturh. Mus. Wien, 48:82 [Palaeodictyoptera]; Martynov, 1938, Trav. Inst. paleont., 7(4):41 [Protodonata]; Carpenter, 1943, Bull. Geol. Soc. Amer., 54:536 [Palaeodictyoptera]; Laurentiaux, 1953, Traité de paléont.:424 [Palaeodictyoptera]; Carpenter, 1954, Bull. Mus. Comp., Zool., $108: 786$ [Palaeodictyoptera]; Kukalová. 1955, Sborník Ústř. Úst. geol., $21: 571$ [Palaeodictyoptera]; Rodendorf, 1962, Osnovy paleont.:52 [Palaeodictyoptera].

Diagnosis. The following diagnosis of the family is based on a study of the type of Calvertiella permiana Tillyard, 1925, as well as on the material from Moravia.

Fore wing: a very short convex veinlet present at the basal part of the costal area; Sc terminating on RI slightly beyond mid-wing; Rs arising before the end of the first third of wing length, with 3-4 main branches; a cuticular thickening (ct) ${ }^{2}$ between $\mathrm{R}$ and $\mathrm{M}$, at about the level of the origin of Rs; stems of $R$ and $M$ independent at the wing base, but approaching each other near the point of origin of Rs; $M$ forking near the level of the origin of Rs; MA unbranched, MP branched; stem of $\mathrm{Cu}$ independent, its branches simple and strongly curved towards posterior margin; $\mathrm{CuA}$ diverging towards $\mathrm{M}$ near the level of origin of $\mathrm{Rs}$ and fusing with it for some distance, or connected with it by means of a short, convex connecting vein; in its further course, $\mathrm{CuA}$ runs very near to the posterior branch of MP; area between $\mathrm{CuA}$ and $\mathrm{CuP}$ broad; 6 anal veins, at least the first 3 arising from one independent stem, all strongly arched, especially the proximal ones; cross veins more or less numerous, forming a reticulation in at least some areas of the wing; intercalary sectors more or less definitely indicated in the radial and medial areas.

Hind wing: broad basally and triangular in shape (Moravia, n.g.) ; anterior margin concave; basal veinlets in costal area somewhat better developed than in the fore wing; Sc terminating much

\footnotetext{
${ }^{1}$ For a discussion of the nomenclatural problems involving the name Protodonata see Carpenter, 1943 and 1954.

${ }^{2}$ Not known in Moraviptera because of poor preservation in the region of the origin of Rs.
} 
as in fore wing; Rs arising slightly more basally than in the fore wing, with about 4 main branches; cuticular thickening as in fore wing; stem of $M$ independent, forked near the level of origin of Rs; MA unbranched, MP branched; stem of $\mathrm{Cu}$ independent, dividing into two simple branches, arched strongly towards posterior margin; $\mathrm{CuA}$ diverging towards $\mathrm{M}$ as in the fore wing, and then continuing close to the posterior branch of MP; 4 anal veins, at least 3 arising from the base independently of each other, somewhat recurved; cross veins numerous, forming a reticulation over much of the wing; intercalary sectors in radial and medial area.

Relationships: The family Calvertiellidae clearly has a very specialized venation and seems far removed from most of the families of the order. This is shown by the short Sc, proximity of $\mathrm{CuA}$ and $\mathrm{MP}$, the wide separation of $\mathrm{CuA}$ and $\mathrm{CuP}$, the curved $\mathrm{CuP}$, recurved anal veins (fore wing) and presence of intercalary sectors. Its closest relatives in the order seem to be the Eugereonidae (including Dictyoptilidae; see Carpenter, 1964, p. 104), which differ from Calvertiellidae in having Sc long and terminating on $\mathrm{C}, \mathrm{CuA}$ more remote from the posterior branch of $\mathrm{MP}, \mathrm{CuP}$ branched and less arched, area between $\mathrm{CuA}$ and $\mathrm{CuP}$ narrower, anal veins less arched, absence of intercalary sectors and of the cuticular thickening. The hind wing of Calvertiellidae is broader than that in the Eugereonidae and more triangular in shape.

It is interesting to find in the wings of the Calvertiellidae a short, simple or branched veinlet, which has now been noted in several families of Palaeodictyoptera (e.g. Breyeriidae, Kukalová, 1958; Spilapteridae, Carpenter, 1964). In Calvertiella it is a simple convex vein, but in the hind wing of Moravia, n.g., it is better developed, with a series of short veinlets. Although this vein may actually be a basal branch of the costa, since the area set off cannot reasonably be considered homologous with the precostal area of the Orthoptera, I have termed it the postcostal area (Kukalová, I963). The vein seems more likely to be homologous with the costal brace of Ephemeroptera, resembling especially the Permian types.

Geological occurrence of family: Lower Permian of Kansas (USA) and Moravia (Czechoslovakia).

Genera included: Calvertiella Tillyard, I925; Moraviptera Kukalová, 1955; Moravia, new genus (herein).

Genus Calvertiella Tillyard

Calvertiella Tillyard, 1925, Amer. Journ. Sci, $10: 43$; Tillyard and Fraser, 1938, Austral. Zool., 9(2):141-142; Fraser, 1957, Royal Zool. Soc. NSW :24. 
Diagnosis. Fore wing: long and slender, broadest before midwing; veins strong, wing membrane thin; anterior margin slightly concave near base, then almost straight; apex slightly directed posteriorly; posterior margin slightly concave at mid-wing; Sc terminating on $\mathrm{R}$ at about the end of the second third of the wing length; RI long; Rs originating before the end of the first third of the wing length, forming three branches, the first forked; an oblique cuticular thickening (ct) running from the very base of $\mathrm{Rs}$ to $\mathrm{M}+\mathrm{CuA} ; \mathrm{M}$ close to $\mathrm{R}$ before, and branching slightly beyond, the level of the origin of Rs; MA simple; MP giving rise to two branches; $\mathrm{Cu}$ dividing before the origin of $\mathrm{Rs}, \mathrm{CuA}$ fused with $\mathrm{M}$ for a short distance, then closely following MP; $\mathrm{CuP}$ simple, arched strongly backwardly; 6 anal veins arising perhaps from a common stem, recurved and slightly sigmoidal; cross veins not dense, mostly simple, forming little reticulation; intercalary sectors distinctly formed.

Relationship: Calvertiella differs from Moraviptera (probably a hind wing) in having $\mathrm{CuA}$ more remote from $\mathrm{MP}$, a three branched MP and more regular cross veins. From Moravia, n.g., it differs in the more slender fore wing, with only three branched $\mathrm{MP}$, the fusion of $\mathrm{CuA}$ with $\mathrm{M}$ for some distance, the absence of supporting cross veins near origin of $\mathrm{R}_{4}+5$, and in having far less dense cross venation and less reticulation.

Type-species: Calvertiella permiana Tillyard.

\section{Calvertiella permiana Tillyard}

Text-figures $\mathrm{I}$ and $4 \mathrm{~A}$; plate 19

Calvertiella permiana Tillyard, 1925, Amer. Journ. Sci., 10:43, figs. 1, 2A.

Fore wing, $27.5 \mathrm{~mm}$ long, $7 \mathrm{~mm}$ broad; about 4 times longer than broad. Intercalary sectors well indicated, convex, irregular reticulation almost absent; first branch of $R s$ with a long fork, the third very short; anal area gradually broadening in the distally, the wing being broadest shortly before the middle.

Tillyard was apparently not aware, when he prepared his account of this fossil, that some tearing and distortion of the wing had taken place in connection with its preservation in the fossil state. In the basal third of the wing, the costal and subcostal areas are broken and pushed posteriorly over the stems of $\mathrm{R}$. At the same time, the anal area was broken and pushed anteriorly over the stem of Ar. Careful removal of small pieces of matrix shows that all of the main veins have independent stems. The drawing in text-figure I depicts these veins restored to their normal positions. Clearing away of 
the matrix also revealed the complicated structure herein designated the cuticular thickening (ct, text-figure $4 \mathrm{~A}$ ). This does not resemble a vein but is a thick, cuticular band which extends from the stem of $\mathrm{M}+\mathrm{CuA}$ to the origin of Rs. It is much more extensively developed in the genus Moravia, described below.

Holotype: No. 5007 (obverse and reverse), Peabody Museum, Yale University; collected in the Wellington Shales, Elmo, Kansas. I am indebted to the authorities of the Peabody Museum for the opportunity of studying this fossil.

\section{Genus Moravia, new genus}

Fore wing: broad, almost oval. Apex very broadly rounded; anterior margin convex; posterior margin even more convex; postcostal area very small and indistinct; Sc terminating on $\mathrm{R}_{\mathrm{I}}$ before the end of the second third of the wing length; RI long; Rs originating before the end of the first third of the wing length, with four branches, the first of them forked; cuticular thickening (ct) arched, starting from $\mathrm{R}$ at the point of origin of Rs, crossing the stem of $M$ and continuing by a convex connecting vein between $M$ and $\mathrm{CuA} ; \mathrm{M}$ approaching $\mathrm{R}$ before the origin of $\mathrm{Rs}$, but not touching it, branching slightly behind the cuticular thickening; MA simple, MP forked three times; $\mathrm{Cu}$ dividing into $\mathrm{CuA}$ and $\mathrm{CuP}$ slightly before the level of the origin of $\mathrm{Rs}$; $\mathrm{CuA}$ approaching close to $M$, connected with $M$ and with the cuticular thickening by a short connecting vein; in its further course, $\mathrm{CuA}$ follows MP closely; area between $\mathrm{CuA}$ and $\mathrm{CuP}$ with many cross veins and a reticulation; curvature of the 6 anal veins becoming more pronounced proximally; cross veins numerous, simple, reticulated in the radial, medial and cubital areas; several cross veins radiating from $R s$ to $R$ and to $M A$ in the proximity of the origin of the first branch of Rs; intercalary sectors present in the radial area.

Hind wing: triangular, very broad basally; anterior margin slightly concave. Postcostal area larger than in the fore wing; Sc terminating on $\mathrm{R}$ somewhat beyond mid-wing. Rs originating at about the end of the first quarter of the wing length, giving rise to about four main branches, the first of them forked; cuticular thickening (ct) arched, starting from the very base of Rs and crossing $M$ at the point where the short convex connecting vein between $M$ and $\mathrm{CuA}$ is starting; stem of $\mathrm{M}$ approaching $\mathrm{R}$ before the origin of $\mathrm{Rs}$, but not touching it, branching some distance beyond the cuticular thickening; MA simple, MP with 4 terminal branches; the stem of 


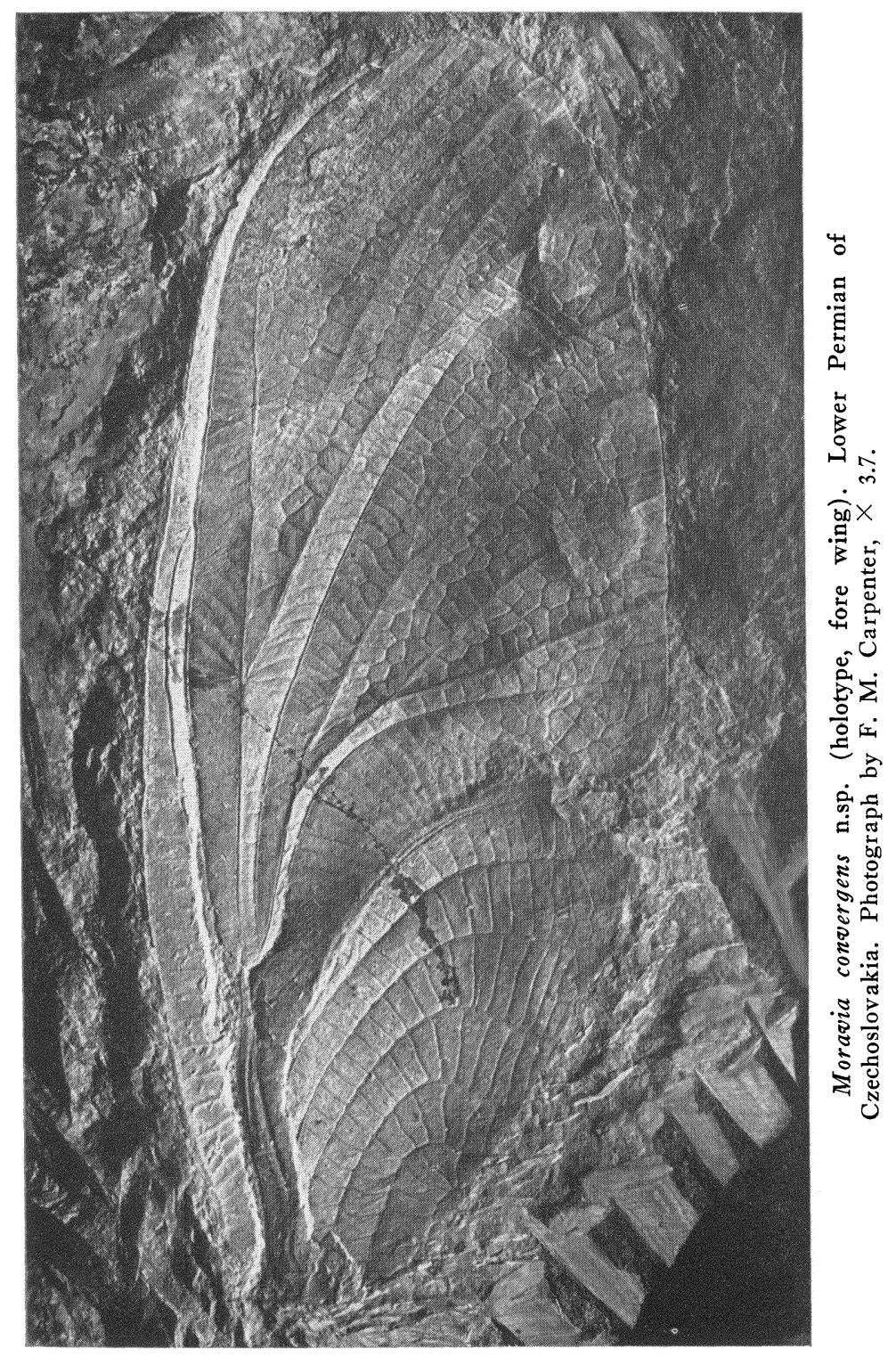




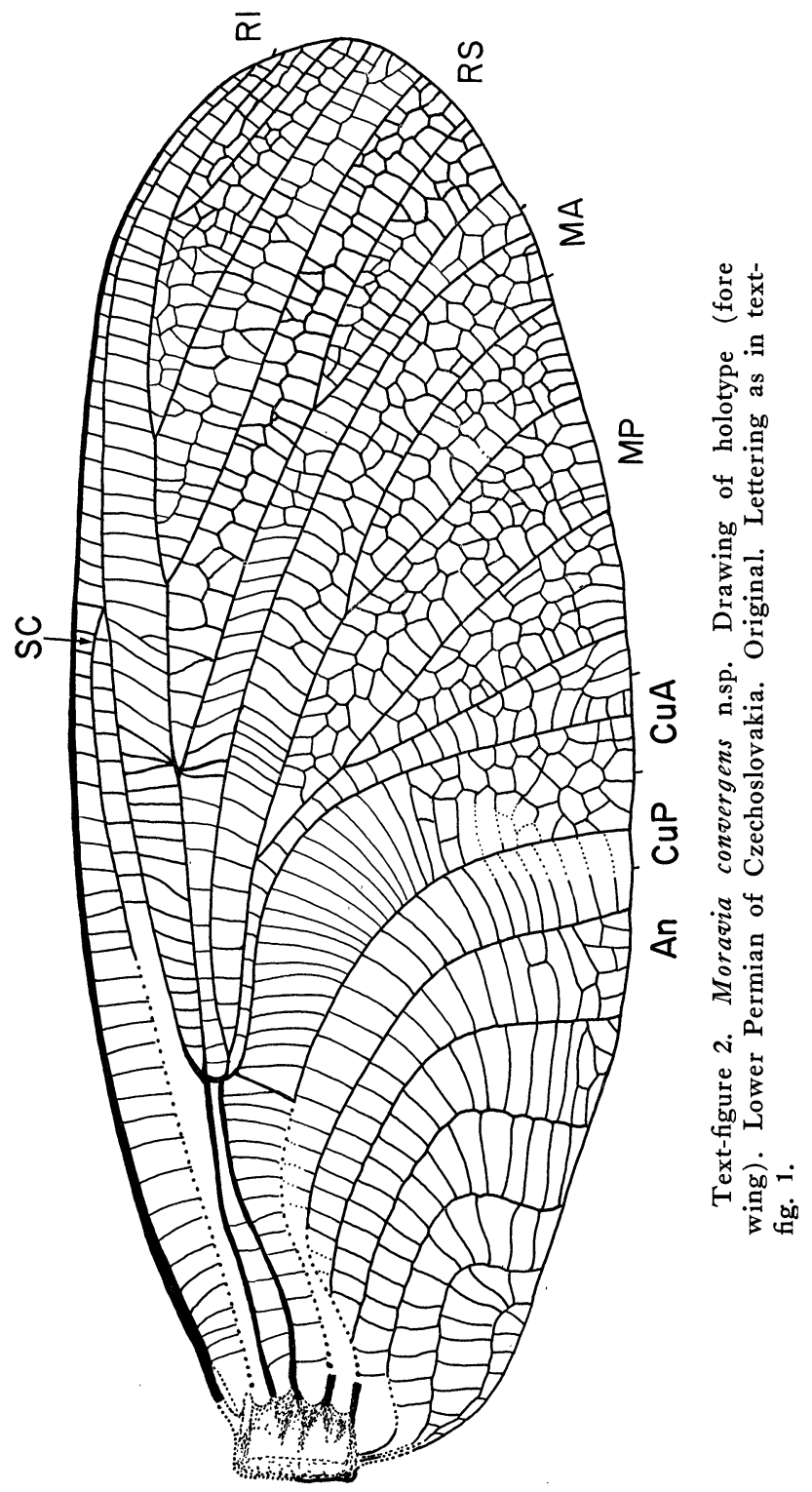


$\mathrm{Cu}$ parallel with the stem of $\mathrm{M}$, dividing well before the origin of Rs; $\mathrm{CuA}$ diverging towards $\mathrm{M}$ and connected to it by a short connecting vein; in its further course, CuA parallel with MP; both cubital branches sigmoidal, directed almost perpendicularly to the posterior margin; area between $\mathrm{CuA}$ and $\mathrm{CuP}$ not broadened; four anal veins, arising independently from the base, arched, rarely branched; cross veins numerous, forming a reticulation in radial, medial, cubital and anal areas; several supporting cross veins radiating from Rs to $\mathrm{RI}_{\mathrm{I}}$ and from $\mathrm{Rs}$ to $\mathrm{MA}$ in about the level of the origin of the first branch of Rs; intercalary sectors well developed in the radial area.

Moravia differs from Calvertiella in the broader and shorter fore wing; Sc is shorter, Rs gives off four main branches, the cuticular thickening is arched, $M$ does not touch R, MP is forked three times, $\mathrm{CuA}$ does not fuse directly with $\mathrm{M}$ and the cross veins and reticulation are much more dense.

From Moraviptera Kukalová ( 1955$)^{4}$, which is apparently a hind wing, it differs in the broader wing, a broader area between MP and $\mathrm{CuA}$ and in presence of more numerous cross veins and a denser reticulation.

Moravia is in many features the most specialized of all the genera of Calvertiellidae, known so far. Its cuticular thickening is highly convex, and continues as a convex connecting vein, forming a transverse "bridge" between $\mathrm{R}$ and $\mathrm{CuA}$. It may have had a function like the arculus in Recent Odonata. The function of the radiating cross veins near the origin of $\mathrm{R}_{4}+5$ was probably that of support.

Both fore and hind wing of Moravia are known. Coloration in the fore wing is absent, but in the hind wing there are irregular pigment spots. The wings differ also little in length, and their venational patterns are very similar. It is impossible to determine whether the fore and hind wings belong to one species, but they are here treated as such.

Stratigraphic occurrence: Lower Permian (Upper Autunian) of Czechoslovakia.

Type-species: Moravia convergens n. sp.

Moravia convergens $n$. sp.

Text-figures $2,3,4 \mathrm{~B},{ }_{4} \mathrm{C}$; plates 20 and $2 \mathrm{I}$.

Fore wing: $38 \mathrm{~mm}$ long and $\mathrm{I} 5 \mathrm{~mm}$ broad, about 2.5 times

\footnotetext{
${ }^{4}$ In the figure of Moraviptera reticulata Kukalová, (1954, p. 548, fig. 3) the origin of $R s$ is not correctly shown; it arises directly from $R$, just before the forking of $M$.
} 
longer than broad. Coloration completely absent; postcostal area short and indistinct; length of Sc slightly variable, as well as the length of the forks on Rs and MP, the width of area between MP and $\mathrm{CuA}$, and the curvature of the anal veins.

Hind wing: about $43 \mathrm{~mm}$ long and $20 \mathrm{~mm}$ broad, about 2.I times longer than broad; triangular in shape. Postcostal area broad and long, with a series of short branches directed towards costa; irregular colored spots concentrated mainly in the posterior half of the wing; fork on the first branch of Rs relatively broad, as well as the fork on MP; area between $\mathrm{CuA}$ and $\mathrm{CuP}$ not very wide, but area between $\mathrm{CuP}$ and IA broad; anal veins arising mostly independently from the base, curving slightly backwards; first two anal veins simple, the third one with a long fork, the fourth simple; reticulation dense, filling the area between $\mathrm{CuP}$ and IA and the anal veins.

Holotype (fore wing): No. I/1965, Department of Palaeontology, Charles University, Prague; collected by Anna Havlatová in Lower Permian shales (Upper Autunian), Obora, Moravia, Czechoslovakia.

Paratype (hind wing): No. 3/1965; collected by Jarmila Kukalová, at the same locality.

Another specimen of a fore wing (No. 2/1965), showing the basal part of the wing especially clearly, also collected at the Obora locality. Its venation is very similar, even in detail, to that of the holotype.

The holotype specimen was apparently distorted in preservation in much the same way as the type of Calvertiella. The wing is broken along Sc and the costal area has shifted towards $\mathrm{R}$, while the anal area is drawn anteriorly across the stems of $\mathrm{Cu}$ and $\mathrm{A}$. Nevertheless, the independent nature of the stems of the main veins can be seen. In text-figure 2, the veins have been restored to their original positions. The dotted lines representing the stems of $\mathrm{Cu}$ and $\mathrm{A}$ have been restored on the basis of those clearly preserved in specimen No. 2/1965.

Discussion: One of the remarkable features of Moravia is the peculiar cuticular thickening, which conceivably acts as a support between $R$ and $M$ at a point where most of the veins of the wing actually diverge. It is clearly developed in Calvertiella (see textfigure $4 \mathrm{~A}$ ), although very short - probably because of the close proximity of $\mathrm{R}$ and $\mathrm{M}+\mathrm{CuA}$ at this point. It is more extensive in the fore wing of Moravia convergens, and much more so in the hind wing. In both wings the cuticular thickening is slightly curved 


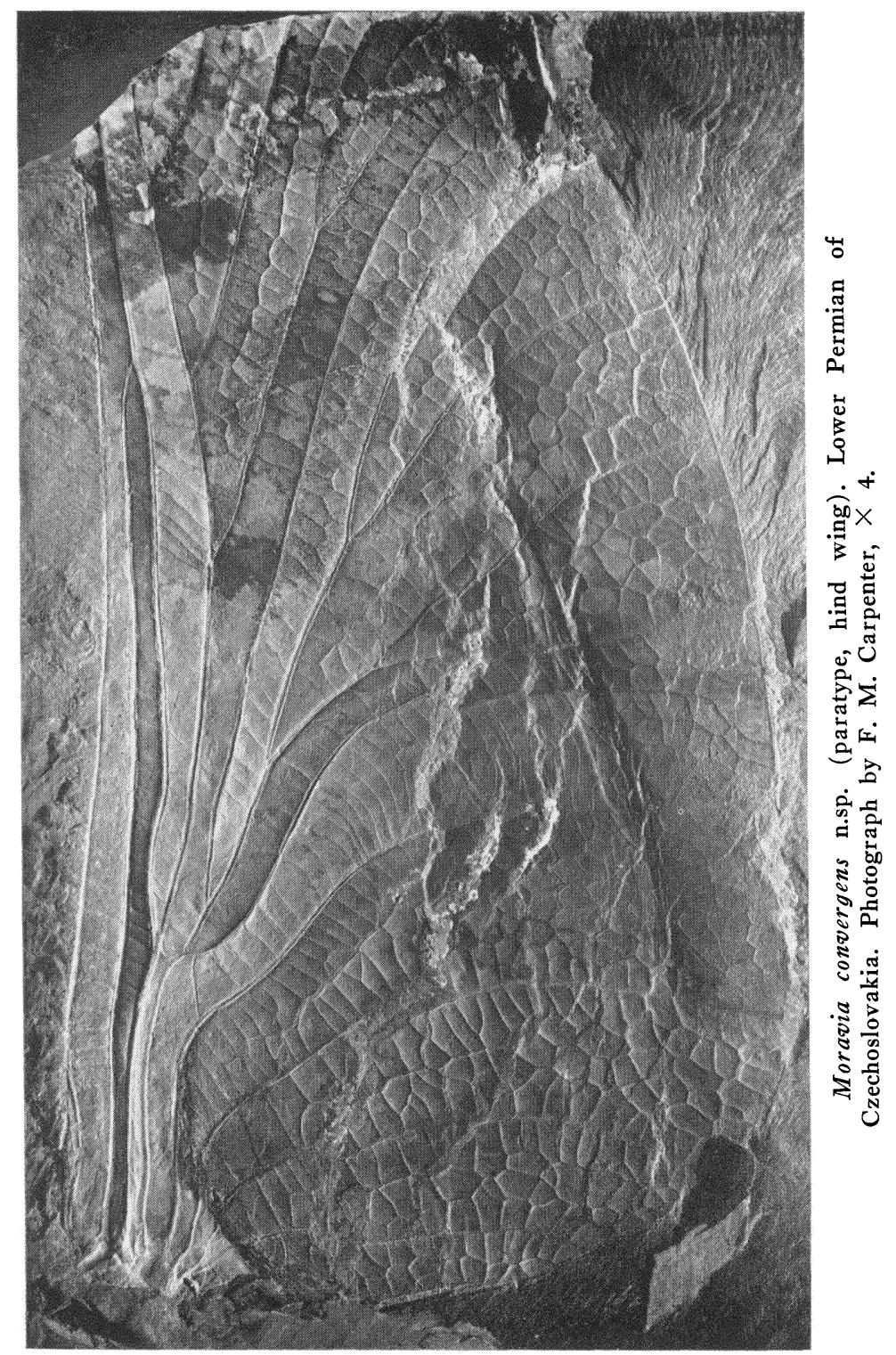




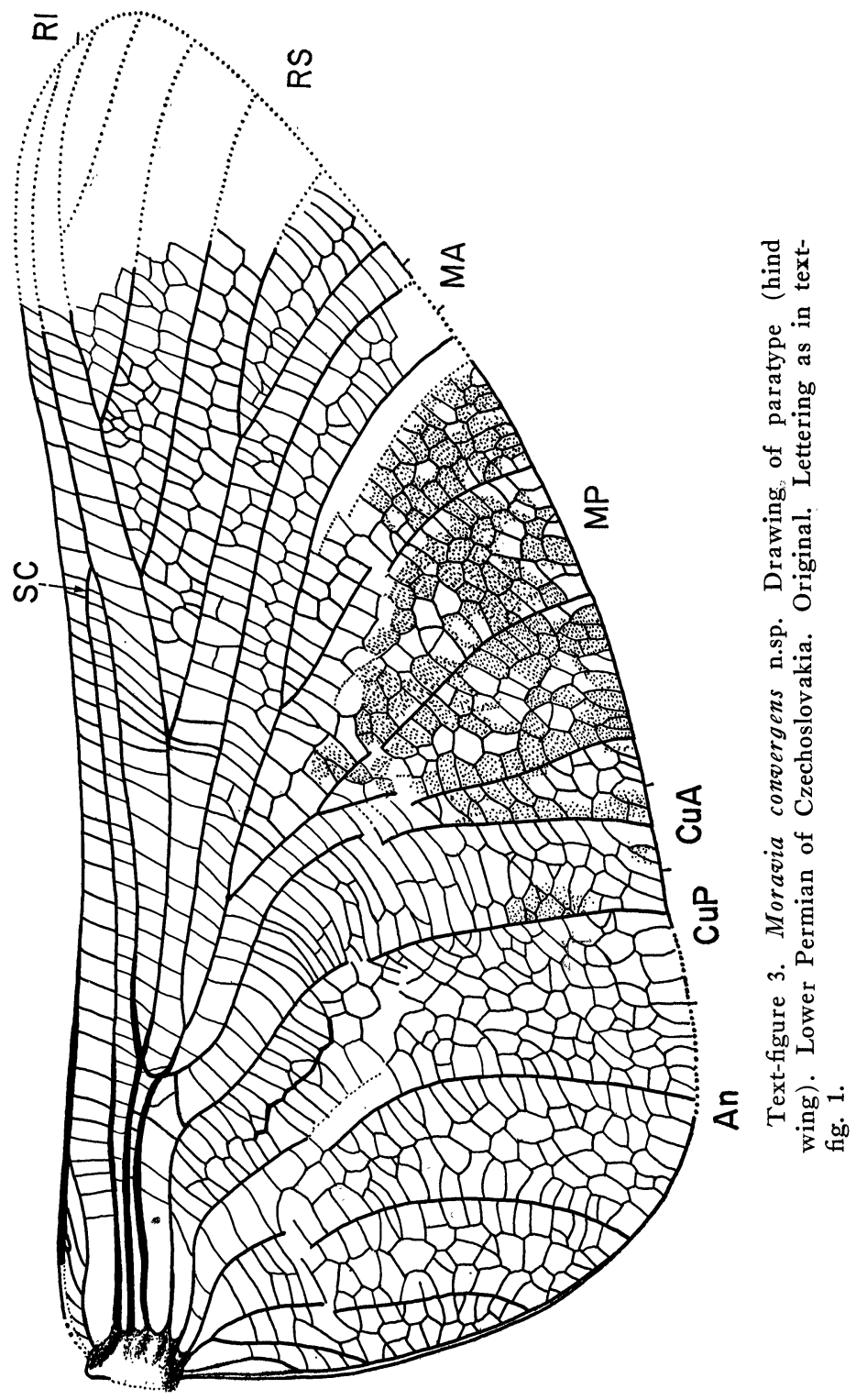



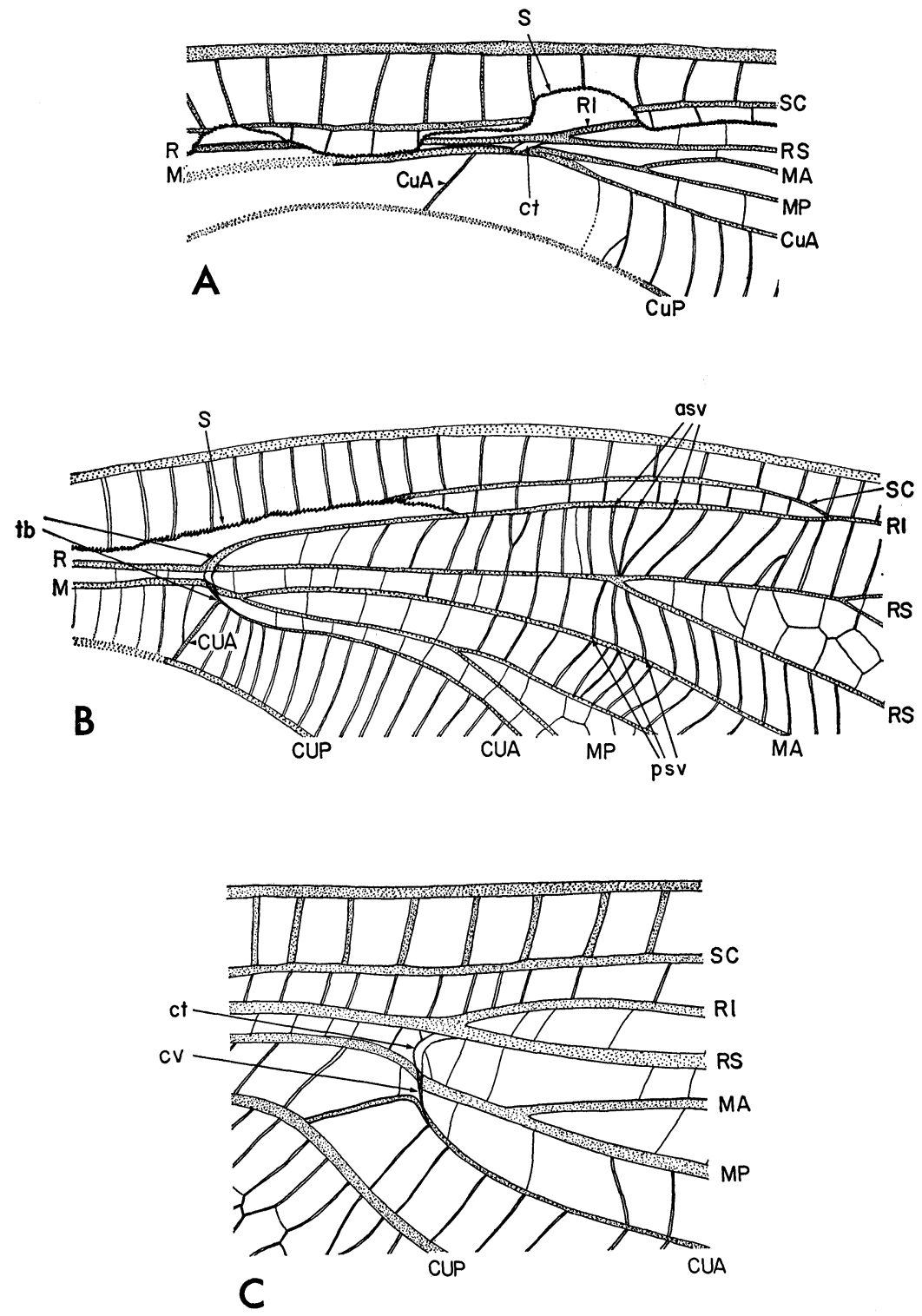

'Text-figure 4 
and seems to lead into the base of $R_{I}$, at least in the fore wing, where it is more convex. It continues posteriorly, seeming to cross $\mathrm{M}$, and finally joins the angle of $\mathrm{CuA}$, which is directed anteriorly. This cuticular arch is herein designated the transverse bridge (tb) and its posterior portion, the connecting vein $(\mathrm{cv})$. It is highly probable that this whole structure functioned in much the same way as the arculus complex in the Odonata. Very different veins are involved in the Odonata, which lack MP and $\mathrm{CuA}$.

The presence of the several radiating cross veins near the origin of $\mathrm{R}_{4}+5$ is another notable feature of Moravia convergens. As can be seen in text-figure ${ }_{4} \mathrm{~B}$, one group of three veins (asv) runs from Rs to $\mathrm{RI}_{\mathrm{I}}$, and the second group (psv) from Rs to MA just below the last group; the cross veins between MA and MP are much closer together than are the others. This structure also looks much like a supporting or strengthening device and recalls to mind the subnodal complex of the Odonata, although the locations of the two sets of structures are very different.

The enlarged anal area of the hind wing of $M$. convergets, as well as the triangular shape of the wing, also recalls the Odonata and, indeed, makes it difficult to realize that this insect, possessing all main veins including $\mathrm{MP}$ and $\mathrm{CuA}$, was a palaeodictyopteron, not an odonate. Moreover, the similarities of the Calvertiellidae to the Eugereonidae make it nearly certain that the Calvertiellidae were haustellate, with a long and highly specialized beak.

Carpenter, F. M.

\section{References Cited}

1943. Studies on Carboniferous Insects from Commentry, France. Part 1. Bull. Geol. Soc. Amer. 54:527-554.

1954. Classification of Insects, in: Brues, Melander, Carpenter. Mus. Comp. Zool. $108: 777-826$.

1960. Studies on North American Carboniferous Insects. 1. The Protodonata. Psyche, $67(4):$ 98-110.

1964. Studies on Carboniferous Insects of Commentry, France. Part 4. The genus Dictyoptilus (Palaeodictyoptera). Psyche, 71(2):104116.

\footnotetext{
Text-figure 4. Details of venational structures in Calvertiellidae:

A. Oblique cuticular thickening (ct) in Calvertiella permiana Till.

B. Arched "transverse bridge" ( $(\mathrm{b})$, anterior supporting cross veins (asv) and posterior supporting cross veins ( $\mathrm{psv}$ ) in Moravia convergens n.sp. (fore wing).

C. Arched "transverse bridge", composed of cuticular thickening (ct) and convex connecting vein (cv) in Moravia convergens n.sp. (hind wing). Lettering as in text-fig. 1. $\mathrm{S}=$ broken edge of wing.
} 
Fraser, F. C.

1957. A reclassification of the Order Odonata. Royal Zool. Soc. NSW: 1-133.

HandliRsch, A.

1937. Neue Untersuchungen ueber die fossilen Insekten. Ann. Naturh. Mus. Wien, $48: 1-140$.

\section{Kukalová, J.}

1955. Permoedischia n.g. (Protorthoptera) and Moraviptera n.g. (Palaeodictyoptera) from the Moravian Permian. Sborník UUG, $21: 541-575$

1963. To the Taxonomy of Palaeodictyoptera (Insecta). Věstník ÚÜG, 38 (3): $197-200$.

LAMEere, A.

1935. Précis de zoologie, $7: 1-468$.

Laurentiaux, D.

1953. Traité de paléontologie, insectes, Paris, 3:397-527.

Martynov, A. V.

1931. On Some New Remarkable Odonata from the Permian of Archangelsk District. Bull. Acad. Sci. URSS, 1:141-147.

1938. Études sur l' histoire geologique et de phylogenie des ordres des insectes (Pterygota). 1-e Partie. Trav. de l' inst. paléont., 7 (4) :1-148.

RODENDORF, B. B.

1962. Osnovy paleontologii, Palaeodictyoptera. Moskva : 50-53.

Tillyard, R. J.

1925. Kansas Permian Insects. Part 5. The Order Protodonata and Odonata. Amer. Journ. Sci. $10: 41-73$.

Tillyard, R. J. ANd F. C. Fraser

1938. A Reclassification of the Order Odonata Based on Some New Interpretations of the Venation of the Dragonfly Wing. Australian Zool. $9(2): 125-396$. 

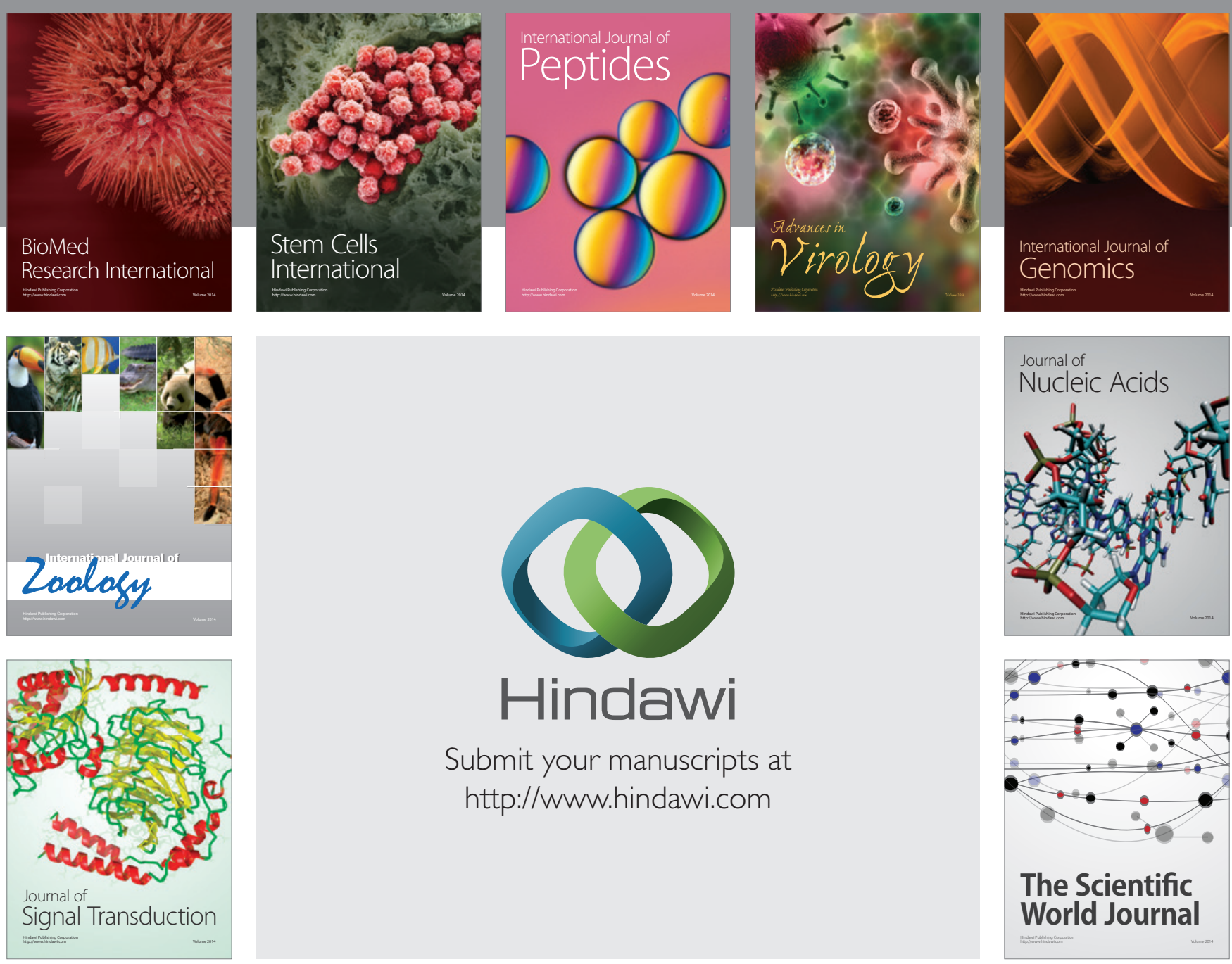

Submit your manuscripts at

http://www.hindawi.com
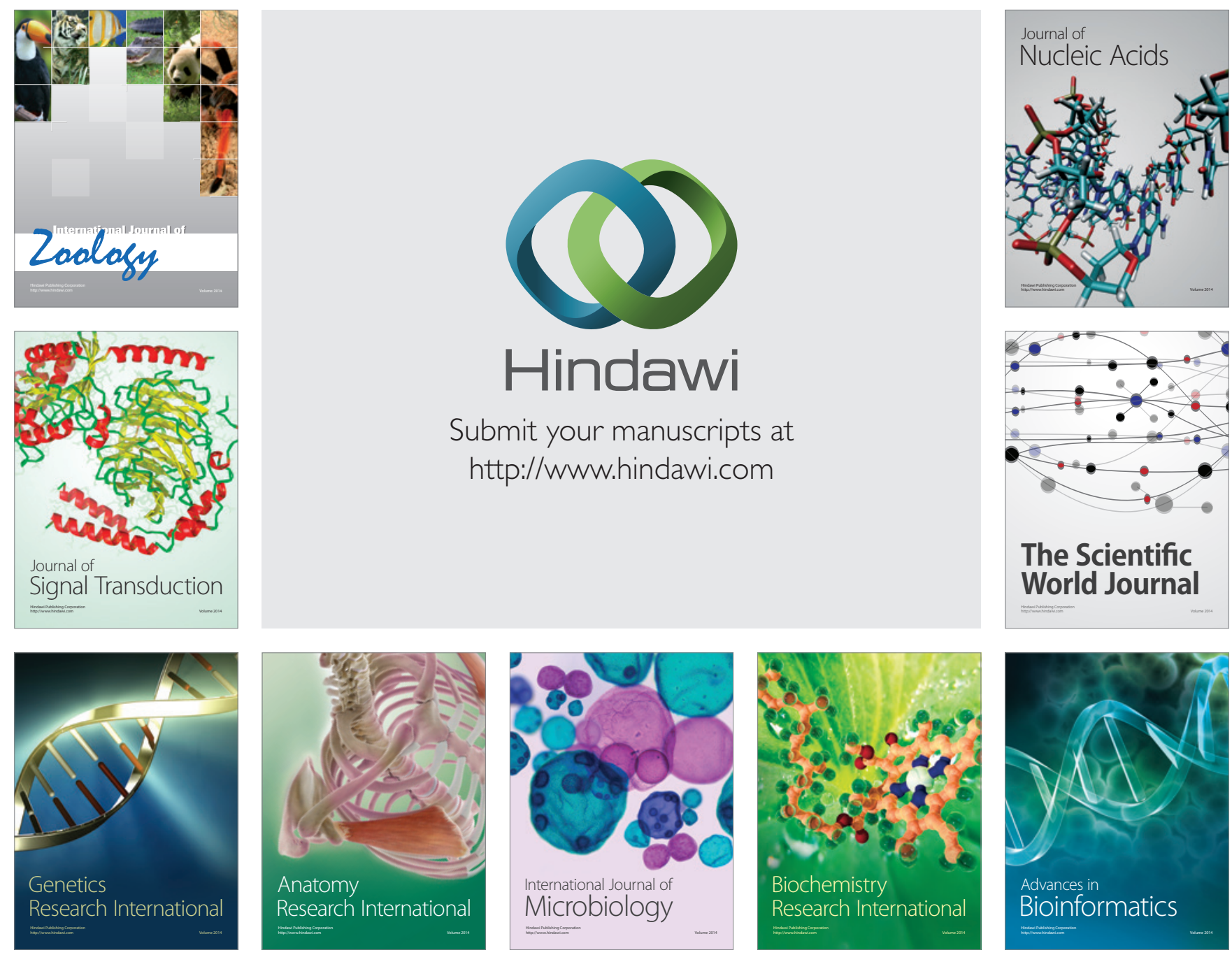

The Scientific World Journal
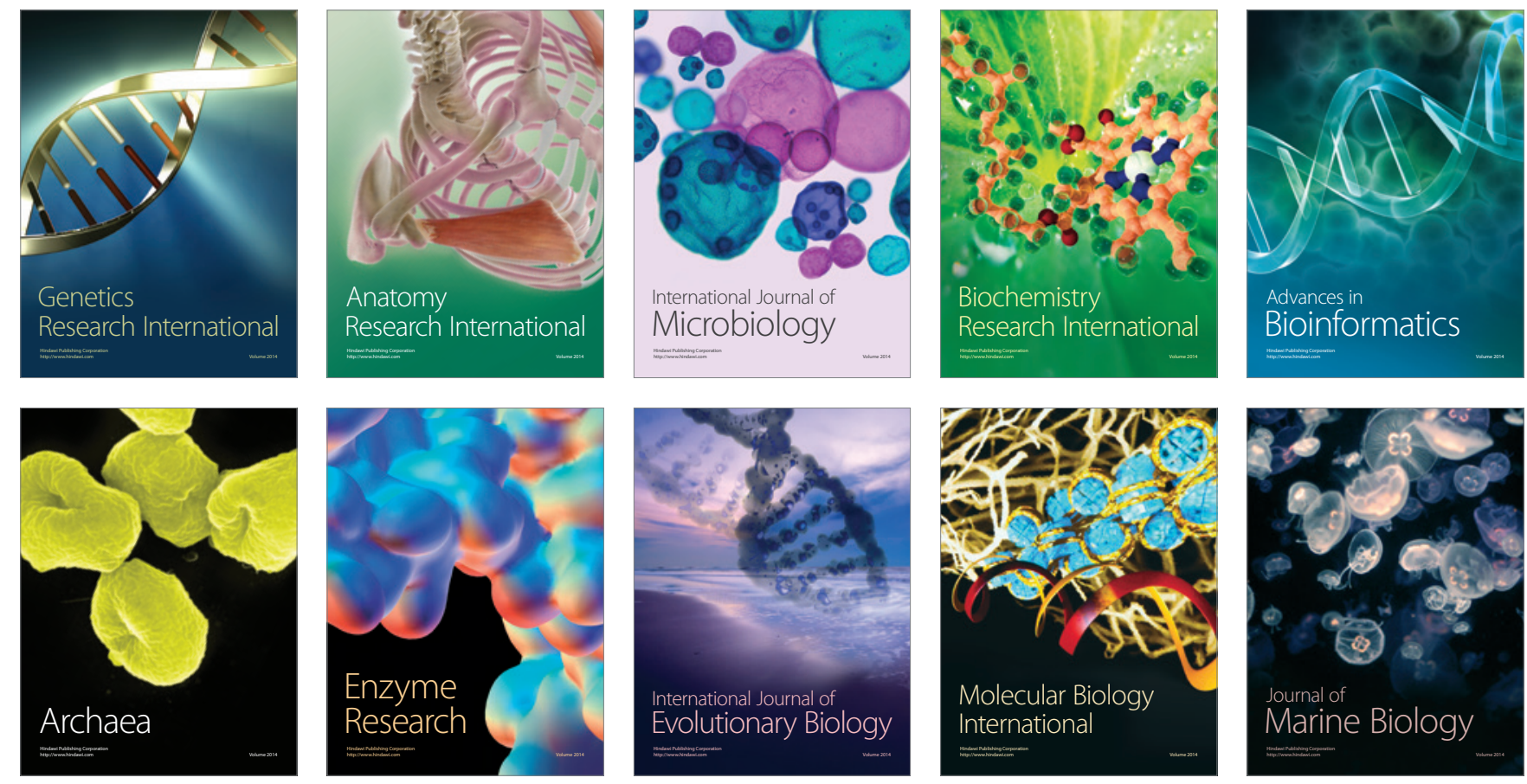